\title{
Plant Species Compositions Alleviate Toxicological Effects of Bisphenol a by Enhancing Growth, Antioxidant Defense System and Detoxification
}

\section{Xianguang Nie}

Ocean University of China - Laoshan Campus: Ocean University of China

Lin Wang ( $D$ lwangouc@163.com)

Ocean University of China - Laoshan Campus: Ocean University of China https://orcid.org/0000-00023228-7574

\section{Research Article}

Keywords: Bisphenol A, plant species compositions, Antioxidant enzymes, Oxidative stress, Detoxification

Posted Date: June 7th, 2021

DOI: https://doi.org/10.21203/rs.3.rs-510009/v1

License: (c) (1) This work is licensed under a Creative Commons Attribution 4.0 International License.

Read Full License 


\section{Abstract}

Bisphenol A (BPA), a broadly disseminated endocrine disturbing chemicals in environment, is harmful to creatures and plants. Plants can uptake and metabolize BPA, but a single plant species ability is limited. Undeniably, plant species compositions have a more vital ability to remove pollutants than a single plant species. However, the mechanisms of plant species compositions alleviating toxicological effects of bisphenol $A$ are poorly understood. Here, we administered plant species compositions, which based on a full-factorial design of Phragmites australis(A), Typha latifolia(B) and Arundo donax(C), to unveil their role in BPA exposure. The comes about illustrated that with $1.5-10 \mathrm{mg} \mathrm{L}^{-1}$ of BPA introduction, the mixedhydroponic culture groups (e.g. $\mathrm{sp}(\mathrm{ABC})$ ) significantly increased biomass production and photosynthetic pigments content as revealed by augmented the shoots fresh, dry weight, chlorophyll a and total chlorophyll content. While mixed-hydroponic culture groups (e.g. $s p(A B), s p(A B C)$ ) significantly increased antioxidant enzymes activity and antioxidant substances, it astoundingly diminished responsive oxygen species (ROS) and malondialdehyde (MDA) substance, proposing that mixed-hydroponic culture groups calmed oxidative stretch in takes off. Further analysis revealed that mixed-hydroponic culture groups (e.g. $s p(A B), s p(A C), s p(A B C)$ ) significantly increased detoxification enzyme activity of NADPH-cytochrome P450 reductase (CPR), glutathione S-transferase (GST) and glycosyltransferase (GT). Moreover, mixedhydroponic culture groups (e.g. $s p(A B), s p(A C), s p(A B C)$ ) decreased the BPA substance in leaves, proposing that mixed-hydroponic culture groups advanced BPA metabolism by improving CPR, GST, GT detoxification. These results suggest that a mixed-hydroponic culture strategy can alleviate BPA phytotoxicity and possibly offer natural and potential phytoremediation of BPA way.

\section{Introduction}

Bisphenol A (Bisphenol A;2, 2-bis (4-hydroxyphenyl) propane) is used industrially to synthesize materials such as polycarbonate and epoxy resins (Staples et al., 1998). BPA is also applied in the production of many commodities, such as toys, water pipes, sports safety equipment, dental unit, medical equipment and pipelines, and electronics materials (Im and Loffler 2016, Wang et al., 2016). Although BPA can be covalently bound to these materials, when they are washed, heated, or come into contact with an acidic or basic $\mathrm{pH}$, the molecules' ester bonds are hydrolyzed, releasing the bisphenol A monomer into the environment (Liu et al., 2013). Due to the tall generation volumes and transfer of items made from BPA BPA has brought about omnipresent within the environment (Maher et al., 2016, Wisniowska et al., 2020). Previous reports have repeatedly affirmed its presence in industrial and municipal effluents and sludge, as well as in fresh water (Lee et al., 2015).

In addition, the concentration of BPA was reported in landfill leachate of hazardous waste, reaching 17.2 $\mathrm{mg} \mathrm{L}^{-1}$ (Yamamoto et al., 2001). Therefore, the BPA moves into the human body through the food chain so that human beings' health is threatened seriously. Previous studies have shown that BPA might cause several diseases such as childhood obesity, type II diabetes, developmental defects, cancer (Guida et al., 2015, Dumitrascu et al., 2020, Martinez et al., 2020). 
Plant is an essential link in a food chain. Plants have the ability to take up BPA from their environment and translocate into above-ground parts, thus exerting severe influences on growth and development of plant (Nakajima et al., 2002).

A number of studies have uncovered the effects of BPA on plant growth, seed germination, photosynthesis, reproduction, reactive oxygen, heritability and antioxidant system in plants (Ferrara et al., 2006, Gattullo et al., 2012, Qiu et al., 2013, Ali et al., 2016, Zhang et al., 2016, Jiao et al., 2017, Ali et al., 2017, Xiang et al., 2018, Kim et al., 2018, Li et al., 2018). The antioxidant responses and "green liver" metabolic pathways are known for their responsiveness to BPA stress (Nakajima et al., 2002, Noureddin et al., 2004, Ali et al., 2016, Ahammed et al., 2020). BPA has been reported to affect the antioxidant system by reactive oxygen species (ROS), which were generated by oxidative stress of plant species (Li et al., 2008, Zhang et al., 2018). Exposure to BPA increased ROS, lipid peroxidation and antioxidant enzymes, which scavenge ROS (Ali et al., 2016, Xiang et al., 2018). “Green liver” metabolic pathways of plant have been shown to detoxify xenobiotics (Bartha et al., 2014, He et al., 2017). Several previous studies found that xenobiotic metabolism of BPA follows three processes in plant cells. To produce more water-soluble compounds, BPA was hydroxylated in phase I via cytochrome P450 (Sasaki et al., 2008, Nakamura et al., 2011, Yu et al., 2019). In phase II, the main product of phase I were conjugated with glycosides, via GT, and glutathione, via GST, to reduce the poisoning of plant cells (Nakajima et al., 2002, Shimoda and Hamada 2009, Ahammed et al., 2020). In phase III, the metabolites of phase II were compartmentalized into the vacuole. Therefore, it is necessary to conduct a complete mechanism study on the toxicity and the degradation pathway of BPA in plants.

Plants get energy from photosynthesis to absorb, retain and assimilate pollutants. However, there are few isolated single plant systems in nature, for in natural ecological environments multiple plant systems coexist (Fornara and Tilman 2008, Wang et al., 2020). Typically, the plants' combining serves to rectify weaknesses of each constituent when it exists alone. A variety of plant combinations have a more vital ability to remove pollutants than a single plant species (Wang et al., 2016, Zhu et al., 2017). However, the plant species compositions alleviating toxicological effects of BPA have never been investigated in detail. This is because plant diversity improves the stability of ecosystem functions and enhances the effect of purifying pollutants (Zheng et al., 2016, Zhu et al., 2017). Therefore, exploring the physiological and biochemical states of various plants in various plant combinations is helpful to understand the mechanism of improving the purification efficiency of plant combinations.

Here, we picked out three macrophytes: Phragmites australis (A), Typha latifolia (B) and Arundo donax (C) who have the biotransformation and bioaccumulation capacity of environmental pollution (Bonanno 2013, He et al., 2017, Hamad 2020). Three macrophytes show a high morphological plasticity and maintain a significant capacity of pollutant removal in different environmental conditions (Calheiros et al., 2009, Zhu et al., 2017, Cao et al., 2019). This study aimed to reveal a suitable plant species composition method for carrying out physiological changes in aquatic plants exposed to BPA. We checked the compositions in terms of biomass production improvement, photosynthetic system pigment content, ROS, lipid peroxidation, antioxidant enzyme activity systems, antioxidant substances, and 
detoxification enzymes. This study will help to understand the reaction mechanism of plant species compositions to BPA. We speculate that the alleviating effect of different plant combinations on BPA may vary with different BPA concentrations. The results of this study will provide a reference for the scientific evaluation of the ecological significance of plant species compositions and the risk of BPA pollution and formulating environmental control measures.

\section{Materials And Methods}

\subsection{Plant cultivation and BPA treatment}

The hydroponic experiment systems were set up in April 2019, which dimension of $22 \times 22 \times 26 \mathrm{~cm}$ and total volume was $12584 \mathrm{~cm}^{3}$. Three common large aquatic plants in China, Phragmites australis (A), Typha latifolia (B), Arundo donax (C), were selected for the experiment. Based on a full-factorial design, three species were assembled into 7 plant combinations, including monocultures of each species (3 combinations) which were named $\mathrm{sp}(\mathrm{A})$-(plant A, Phragmites australis), $\mathrm{sp}(\mathrm{B})$-(plant $\mathrm{B}$, Typha latifolia), $\mathrm{sp}(\mathrm{C})$-(plant $\mathrm{C}$, Arundo donax), all possible two-species mixtures (3 combinations) which were named $\mathrm{sp}(\mathrm{AB})$-(plant A + B, Phragmites australis + Typha latifolia), $\mathrm{sp}(\mathrm{AC})$-(plant A + C, Phragmites australis + Arundo donax), $\mathrm{sp}(\mathrm{BC})$-(plant $\mathrm{B}+\mathrm{C}$, Typha latifolia + Arundo donax), and a three-species mixture of all species which is named $\mathrm{sp}(\mathrm{ABC})$-(plant $\mathrm{A}+\mathrm{B}+\mathrm{C}$, Phragmites australis + Typha latifolia + Arundo donax). The plant density was settled in each hydroponic box in diverse cultured types. Each hydroponic box contained 12 individual plants, evenly distributed (i.e., 1:1 in $\mathrm{sp}(\mathrm{AB}) / \mathrm{sp}(\mathrm{AC}) / \mathrm{sp}(\mathrm{BC})$ or 1:1:1 in $\mathrm{sp}(\mathrm{ABC})$ ), with each plant combination had 3 replicates (hydroponic box). In order to immobilize the pot and aquatic plants in the exposure medium, the commercially available stones were placed in each pot. All aquatic plant were allowed to acclimate in the hydroponic box of tap water for about ten days and then Hoagland medium ten days. The hydroponic experiment systems were fed with Hoagland medium, holding pH about 6.0. Next, each hydroponic box was filled with $10 \mathrm{~L}$ of Hoagland medium and supplemented with a total four concentrations of BPA $\left(1.5,5,10\right.$ and $\left.20 \mathrm{mg} \mathrm{L}^{-1}\right)$, which was renewed every two days for ten days. The hydroponic test was ended at ten days after start of BPA treatment. Shoot of Plants were collected for the investigation of diverse biochemical parameters.

\subsection{Determination of biomass and light harvesting pigments}

fresh weights of shoots were measured and kept in an oven at $80^{\circ} \mathrm{C}$ for $96 \mathrm{~h}$ until a constant weight. The content of Chlorophyll a and total Chlorophyll pigments from leaves were measured according to a method described by Arnon (Arnon 1949). Fresh leaf samples $(0.10 \mathrm{~g})$ were placed in a $2 \mathrm{~mL}$ of absolute alcohol in dark. After $48 \mathrm{~h}$,the ethanolic extracts were measured using UV-vis spectrophotometer (UV2550, Shimadzu Corporation, Japan) and scanned at 645 and $663 \mathrm{~nm}$ for absorbance (OD). The gotten absorbance values were utilized to calculate Chlorophyll a and total Chlorophyll content.

Chlorophyll a content $=13.95 *$ OD $663-6.88 *$ OD 645

total Chlorophyll content $=20.2 *$ OD $645+8.02 *$ OD 663 


\subsection{Assay of ROS levels and membrane lipid peroxidation}

Superoxide anion $\left(\mathrm{O}_{2}{ }^{-}\right)$contents were measured according to previous methods (Elstner and Heupel 1976). The absorbance was recorded at $530 \mathrm{~nm}$ (UV-2550 spectrophotometer, Shimadzu Corporation, Japan). Hydrogen peroxide $\left(\mathrm{H}_{2} \mathrm{O}_{2}\right)$ contents were determined according to previous methods (Patterson et al., 1984). The absorbance was recorded at $412 \mathrm{~nm}$ (UV-2550 spectrophotometer, Shimadzu Corporation, Japan). Hydroxyl radical $(\cdot \mathrm{OH})$ contents were determined according to previous methods with slight modification (Pandey et al., 2016). The absorbance was recorded at $532 \mathrm{~nm}$ (UV-2550 spectrophotometer, Shimadzu Corporation, Japan).

The malondialdehyde (MDA) content was determined according to previous methods with slight modification (Heath and Packer 1965). The absorbance was recorded at $532 \mathrm{~nm}$ (UV-2550 spectrophotometer, Shimadzu Corporation, Japan).

\subsection{Determination of antioxidant enzyme activity}

The fresh leaves $(1.00 \mathrm{~g})$ were homogenized in a $50 \mathrm{mM}$ PBS ( $\mathrm{pH}$ 7.8) containing $5 \mathrm{mM}$ EDTA, $5 \mathrm{mM}$ dithiothreitol and $1 \%(\mathrm{v} / \mathrm{v})$ polyvinylpyrrolidone under ice cold conditions. The homogenates were centrifuged and the supernatants were used to perform following enzyme assays.

The superoxide dismutase (SOD) activity was assayed by according to Du (Du et al., 2015). The reaction mixture reacted about30 min in fluorescent lights. One unit of SOD activity was defined as the cause $50 \%$ inhibition of the NBT measured at $560 \mathrm{~nm}$ within $1 \mathrm{~min}$ (UV-2550 spectrophotometer, Shimadzu Corporation, Japan).

The peroxidase (POD) activity was measured by following Maehly and Chance (Maehly and Chance 1954). The reaction mixture ( $3 \mathrm{~mL}$ ) contained $1 \mathrm{~mL}$ of $50 \mathrm{mM} \mathrm{PBS}(\mathrm{pH} 6.8), 2 \%$ guaiacol, $2 \% \mathrm{H}_{2} \mathrm{O}_{2}$, and $100 \mu \mathrm{L}$ enzyme extract. The change of absorbance was recorded at $470 \mathrm{~nm}$ within $1 \mathrm{~min}$ (UV-2550 spectrophotometer, Shimadzu Corporation, Japan).

The activity of catalase (CAT) was assayed by according to previous methods with little modifications (Jiang and Zhang 2001). The reaction mixture contained $200 \mathrm{mM} \mathrm{PBS} \mathrm{(pH} \mathrm{7.8),} 100 \mathrm{mM} \mathrm{H}_{2} \mathrm{O}_{2}$ and $50 \mu \mathrm{L}$ of enzyme extract. The change of absorbance was recorded at $240 \mathrm{~nm}$ within $1 \mathrm{~min}$ (UV-2550 spectrophotometer, Shimadzu Corporation, Japan).

\subsection{Determination of non-enzymatic antioxidant substance content}

The ascorbic acid (AsA) content was measured in accordance with previous methods (Singh et al., 2006). The fresh leaves $(0.20 \mathrm{~g})$ were homogenized in $5 \%$ TCA and centrifuged. The reaction mixture stored 0.1 $\mathrm{mL}$ supernatant, $0.9 \mathrm{~mL}$ PBS (pH 7.4) and $1 \mathrm{~mL}$ deionized water. The absorbance was recorded at $525 \mathrm{~nm}$ (UV-2550 spectrophotometer, Shimadzu Corporation, Japan). 
The Glutathione (GSH) content was assayed by according to previously methods with slight modification (Devos et al., 1992). The fresh leaves $(0.20 \mathrm{~g})$ were homogenized in $5 \%$ TCA and centrifuged $15 \mathrm{~min}$ at $4^{\circ} \mathrm{C}$. The reaction mixture contained $0.1 \mathrm{~mL}$ supernatant, $2.6 \mathrm{~mL}$ PBS $(\mathrm{pH} 7.7)$ and $0.18 \mathrm{~mL} 5,5$-dithiobis(2-nitrobenzoic acid). The absorbance was recorded at $412 \mathrm{~nm}$ (UV-2550 spectrophotometer, Shimadzu Corporation, Japan).

The free proline (Pro) content was estimated according to previously methods with slight modification (Troll and Lindsley 1955). The fresh leaves $(0.20 \mathrm{~g})$ were homogenized in $10 \mathrm{~mL}$ of $3 \%$ sulfosalicylic acid and centrifuged for $10 \mathrm{~min}$ at $4^{\circ} \mathrm{C}$. The reaction mixture contained supernatant, ice acetic acid and $2.5 \%$ ninhydrin (1:1:1 V/V). The absorbance was recorded at $520 \mathrm{~nm}$ (UV-2550 spectrophotometer, Shimadzu Corporation, Japan).

\subsection{Determination of detoxification enzyme activity}

The microsomes are extracted according to previously reported with slight modification (Tan et al., 2015). The fresh leaves about $5 \mathrm{~g}$ were homogenized in 2 volumes of $50 \mathrm{mM}$ PBS $(\mathrm{pH} \mathrm{7.8)}$ and then was centrifuged at $10,000 \times g$ for $10 \mathrm{~min}$ at $4^{\circ} \mathrm{C}$. The supernatant was centrifuged at $100,000 \times g$ for $60 \mathrm{~min}$ and then the pellet was resuspended in $100 \mathrm{mM}$ PBS (pH 7.8), containing 25\% (v/v) glycerol and $10 \mathrm{mM}$ mercaptoethanol.

The NADPH-cytochrome P450 reductase (CPR) activity was determined by the method described previously with slight modification (Guengerich et al., 2009). The reaction mixture $(2 \mathrm{~mL})$ contained 0.05 $\mathrm{mL}$ microsomal suspension, $5 \mathrm{mg} \mathrm{mL}^{-1}$ cytochrome c, $50 \mathrm{mM}$ PBS (pH 7.8), $10 \mathrm{mM} \mathrm{NADPH}$. The absorbance was recorded at $550 \mathrm{~nm}$ (UV-2550 spectrophotometer, Shimadzu Corporation, Japan). The enzyme activity was expressed as nmol $\mathrm{min}^{-1} \mathrm{mg}^{-1}$ protein using a millimolar extinction coefficient of $21.1 \mathrm{~cm}^{-1}$.

The glutathione S-transferase (GST) activity was determined by a modified protocol as described previously (Fuerst et al., 1993). The fresh leaves (about $1.00 \mathrm{~g}$ ) were homogenized in $100 \mathrm{mM} \mathrm{PBS} \mathrm{(pH}$ 7.8) and centrifuged for $10 \mathrm{~min}$ at $4^{\circ} \mathrm{C}$. The reaction mixture $(2 \mathrm{~mL})$ contained $0.05 \mathrm{~mL}$ supernatant, $\mathrm{GSH}$, 1-Chloro-2,4-dinitrobenzene and PBS ( $\mathrm{pH}$ 7.8). The enzyme activity was expressed as nmol $\mathrm{min}^{-1} \mathrm{mg}^{-1}$ protein using a millimolar extinction coefficient of $9.6 \mathrm{~cm}^{-1}$.

The glycosyltransferases (GT) activity was determined according to previously methods with slight modification (Zhang et al., 2017). The fresh leaves (about $1.00 \mathrm{~g}$ ) were homogenized in 100mM PBS (pH 7.8) and centrifuged at $4^{\circ} \mathrm{C}$ for $30 \mathrm{~min}$. The reaction mixture was contained $100 \mu \mathrm{L}$ supernatant, UDPglucose and p-nitrophenol. The reaction mixture was added with $250 \mu \mathrm{L}$ methanol and chilled at $-20^{\circ} \mathrm{C}$ for $0.5 \mathrm{~h}$. The reaction mixture was analyzed using high performance liquid chromatography (LC-20A HPLC, Shimadzu Corporation, Japan) with a ultraviolet (UV) detection. One unit of the GT activity was defined as the consumption of $1 \mu \mathrm{mol}$ p-nitrophenol per minute.

\subsection{Measurement of BPA content}


Leaves of BPA content was estimated by high performance liquid chromatography (HPLC) as described previously with slight modification (Loffredo et al., 2010). The fresh leaves were dried until a constant weight. The dried leaves $(1.00 \mathrm{~g})$ were homogenized in $5 \mathrm{~mL}$ methanol and shaken on an oscillator for 4 h. The supernatant was evaporated off using a rotary vacuum evaporator $\left(40^{\circ} \mathrm{C}\right)$. The residual product was homogenized in $5 \mathrm{~mL}$ of $60 \%(\mathrm{v} / \mathrm{v})$ acetonitrile. The supernatant was filtered through a $0.45 \mu \mathrm{m}$ Millipore $^{\mathrm{TM}}$ filters and analyzed using HPLC (LC-20A, Shimadzu Corporation, Japan) with a ultraviolet (UV) detection under the condition: Inertsil ODS-3 column ( $4.6 \times 250 \mathrm{~mm}, 5 \mu \mathrm{m}), 217 \mathrm{~nm}$ wavelength, 70\% methanol mobile phase, $0.6 \mathrm{~mL} \mathrm{~min}^{-1}$ flow rate, $20 \mu \mathrm{L}$ of the injection volume. Residual BPA content was calculated by standard curve which uses BPA samples with known concentration.

\subsection{Statistical analysis}

All assays were conducted in triplicate replications. The results were expressed as the mean \pm standard deviation. Treatment groups and control were analyzed by variance (ANOVA); $<<0.05$ was considered statistically significant (SPSS 22.0, IBM).

\section{Results And Discussion}

\section{1 mixed-hydroponic culture groups improve biomass production}

After $10 \mathrm{~d}$ of exposure to BPA, variation of the shoots fresh and dry weight of seven cultured groups of the single species seedlings were observed in Fig. 1. With increase of BPA concentration, the shoots fresh and dry weight were increased first and then decreased respectively as compared to $0 \mathrm{mg} \mathrm{L}^{-1} \mathrm{BPA}$ treatment. This phenomenon is in agreement with previous studies that BPA concentrations has a cytokinin-like effect, inducing plant cell elongation and proliferation, thereby promoting plant growth to a certain extent (Li et al., 2018, Xiao et al., 2019). Concentrations of BPA even destroyed the cell structural integrity (Ali et al., 2016, Kim et al., 2018). The shoots fresh and dry weight existed significant differences from $1.5 \mathrm{mg} \mathrm{L}^{-1}$ to $10 \mathrm{mg} \mathrm{L}^{-1}$ BPA concentrations, respectively as compared to single species control $(s p(A), s p(B), s p(C))$. Consequently, the shoots fresh and dry weight of $s p(A B C-A), s p(A B C-B)$ and $s p(A B C-$ $C)$, which three plant species compositions formed $\operatorname{sp}(A B C)$, were significantly increased in $1.5 \mathrm{mg} \mathrm{L}^{-1}$ to $10 \mathrm{mg} \mathrm{L}^{-1}$ concentrations of BPA. In detail, the shoots fresh and dry weight of $\mathrm{sp}(\mathrm{ABC}-\mathrm{A}), \mathrm{sp}(\mathrm{ABC}-$ $B$ ), $s p(A B C-C)$ were increased by a maximum of 11.66 and $21.21 \%, 7.90$ and $22.01 \%, 8.31$ and $21.38 \%$, respectively. This result recommends that upgrading plant species diversity will result in utilizing more pollutants for higher biomass production (Gross 2008, Fornara and Tilman 2009, Zhu et al., 2017).

\subsection{Effect on chlorophyll a and total chlorophyll content}

Chlorophyll plays a pivotal role in light capture and photosynthesis (Wang et al., 2020, Wang et al., 2020). It traps light energy and provides reducing power for carbon assimilation. To further explore the effect of BPA on chlorophyll, chlorophyll a and total chlorophyll content in seedlings leaves were determined in 
Fig. 2. The chlorophyll a and total chlorophyll content were increased first and then decreased with increasing BPA concentration. Several studies have been reported in soybean and Vigna radiata chlorophyll content induced by bisphenol A (Qiu et al., 2013, Kim et al., 2018). It may be speculated that low concentration of BPA leaded to hormesis phenomenon. High concentration of BPA increased the accumulation of ROS, which have damaged the pigments and interfered key enzyme in chlorophyll synthesis (Qiu et al., 2013, Jiao et al., 2015, Jiao et al., 2017). Chlorophyll a and total chlorophyll content of $s p(A B-A), s p(A C-A), s p(A B C-A), s p(A B-B), s p(A B C-B), s p(A C-C)$ and $s p(A B C-C)$ were significantly higher from $1.5 \mathrm{mg} \mathrm{L}^{-1}$ to $10 \mathrm{mg} \mathrm{L}^{-1} B P A$ concentrations, as compared to single species control(sp(A), $s p(B)$, $s p(C))$ respectively. Chlorophyll a content of $s p(A B-A), s p(A C-A), s p(A B C-A), s p(A B-B), s p(A B C-B), s p(A C-C)$ and $\operatorname{sp}(A B C-C)$ were increased by a maximum of $14.07,13.01,14.89,19.44,19.93,15.80,18.95 \%$, respectively, and total chlorophyll content were increased by a maximum of $11.39,11.98,11.26,17.42$, $16.98,13.96,13.23 \%$, respectively. It follows that three cultured groups of $s p(A B), s p(A C)$ and $s p(A B C)$ were increased in chlorophyll a and total chlorophyll content. These results suggest that plant compositions improved stress tolerance and delayed chlorophyll degradation.

\section{3 plant compositions reduced ROS accumulation and lipid peroxidation}

Environmental stress can produce the reactive oxygen species (ROS), which is residual products of various categories metabolic pathways in plant cell (Ali et al., 2017). ROS accumulation exceed the antioxidant scavenging capacity and created oxidative stress in chloroplasts, plasma membrane, mitochondria and peroxisomes (Biczak et al., 2017). Malonaldehyde (MDA) characterizes the oxidative damage to lipid membranes to plants (Ali et al., 2016). Figure 3 shows the endogenous levels of $\mathrm{O}_{2}{ }^{-}$, $\mathrm{H}_{2} \mathrm{O}_{2}, \cdot \mathrm{OH}$ and MDA content in all large aquatic plants exposed to different concentrations of BPA. The levels of $\mathrm{O}_{2}{ }^{-}, \mathrm{H}_{2} \mathrm{O}_{2}, \cdot \mathrm{OH}$ and MDA contents in the leaves were increased with the increase BPA concentration. Increases in levels of ROS indicate that the presence of BPA triggered oxidative stress responses and lead to adding MDA content and lipid peroxidation (M. Dogan 2010, Wang et al., 2015, Zhang et al., 2016, Pawlowska et al., 2019). ROS may be responsible for inhibiting biomass and making chlorophyll degradation. The levels of $\mathrm{O}_{2}{ }^{-}, \mathrm{H}_{2} \mathrm{O}_{2}, \cdot \mathrm{OH}$ and MDA contents of all single species of $\operatorname{sp}(\mathrm{AB})$, $s p(A C)$ and $s p(A B C)$ groups significantly lower than single species control $(s p(A), s p(B), s p(C)$ ), respectively, from $5 \mathrm{mg} \mathrm{L}^{-1}$ to $10 \mathrm{mg} \mathrm{L}^{-1} \mathrm{BPA}$ exposure. Compared to $\mathrm{sp}(\mathrm{A}), \mathrm{sp}(\mathrm{B}), \mathrm{sp}(\mathrm{C})$, the $\mathrm{O}_{2}{ }^{-}, \mathrm{H}_{2} \mathrm{O}_{2}$, $\cdot O H$ levels and MDA contents of $s p(A B-A), s p(A B-B), s p(A C-A), s p(A C-C), s p(A B C-A), s p(A B C-B)$ and sp(ABC-C) were remarkably decreased in $5 \mathrm{mg} \mathrm{L}^{-1}$ to $10 \mathrm{mg} \mathrm{L}^{-1} \mathrm{BPA}$. In summary, the levels of $\mathrm{O}_{2}{ }^{-}, \mathrm{H}_{2} \mathrm{O}_{2}$, $\cdot \mathrm{OH}$ and MDA contents were all relieved stress in $\mathrm{sp}(\mathrm{AB}), \mathrm{sp}(\mathrm{AC})$ and $\mathrm{sp}(\mathrm{ABC})$ group. For example, the levels of $\mathrm{O}_{2}{ }^{-}, \mathrm{H}_{2} \mathrm{O}_{2}, \cdot \mathrm{OH}$ and MDA contents of $\mathrm{sp}(\mathrm{AB}-\mathrm{A})$ and $\mathrm{sp}(\mathrm{AB}-\mathrm{B})$, which make up $\mathrm{sp}(\mathrm{AB})$, were reduced by a maximum of $13.69,28.16,8.66,6.21 \%$ and $10.83,29.22,13.33,6.13 \%$, respectively. The levels of $\mathrm{O}_{2}{ }^{-}, \mathrm{H}_{2} \mathrm{O}_{2}, \cdot \mathrm{OH}$ and MDA contents of $\mathrm{sp}(\mathrm{ABC}-\mathrm{A})$ and $\mathrm{sp}(\mathrm{ABC}-\mathrm{B})$ and $\mathrm{sp}(\mathrm{ABC}-\mathrm{C})$, which make up $\mathrm{sp}(\mathrm{ABC})$, were reduced by a maximum of $14.90,28.18,10.56,7.19 \%$ and $11.36,36.68,14.10,7.18 \%$ and 
$10.39,27.69,12.92,4.37 \%$, respectively. It indicates that levels of $\mathrm{O}_{2}{ }^{-}, \mathrm{H}_{2} \mathrm{O}_{2}, \cdot \mathrm{OH}$ and MDA contents were relaxed and relieved stress by mixed-hydroponic culture groups. It is well known that ROS (especially $\cdot \mathrm{OH}$ ) participate in the degradation of BPA and decrease BPA (Wang and Lim 2011, Reis et al., 2014). On some certain conditions, ROS can be converted to each other (Mattila et al., 2015). Hence, this relieved phenomenon was probably correlated with the production of ROS (especially $\cdot \mathrm{OH}$ ) by biological Fenton reaction, Haber-Weiss reactions and antioxidant enzyme reaction (Halliwell 1999, Reis and Sakakibara 2012). Similar observed effects were reported by previous studies (Wang et al., 2015, Inagaki et al., 2016, Zhang et al., 2018).

\subsection{Effect of BPA on antioxidant enzymes activities}

To defend plant organism from oxidative stress, plants have an antioxidant defense mechanism that can scavenge ROS in cell (Xiao et al., 2020). The production and cleanup of ROS exists in homeostasis in vivo, the excessive ROS can damage the plant organism (Czarnocka and Karpinski 2018). Hence, antioxidant enzymes play a key role in clearing up excess ROS or changing them, which include SOD, POD and CAT. Protecting cells from $\mathrm{O}_{2}{ }^{-}$toxicity, SOD catalyzes the disproportionation of $\mathrm{O}_{2}{ }^{-}$to $\mathrm{O}_{2}$ and $\mathrm{H}_{2} \mathrm{O}_{2} \cdot \mathrm{H}_{2} \mathrm{O}_{2}$ are further converted to non-toxic oxygen and water by CAT and POD (Xu et al., 2008). In order to investigate the response of all large aquatic plants to BPA stress, the activities of SOD, POD and CAT in leaves were measured (Fig. 4). It was found that SOD, POD and CAT activities were increased after BPA exposure. This result indicated that BPA stress induced an enhanced in antioxidant enzymes activities, which effectively eliminated ROS to protect normal physiological functions of plant. In comparison to single species control $(\mathrm{sp}(\mathrm{A}), \mathrm{sp}(\mathrm{B}), \mathrm{sp}(\mathrm{C}))$, the $S O D, P O D$ and CAT activities of all single species of $s p(A B), s p(A C), s p(B C)$ and $s p(A B C)$ groups were significantly increased after $10 \mathrm{~d}$ of $5 \mathrm{mg} \mathrm{L}^{-1}$ and $10 \mathrm{mg} \mathrm{L}^{-1}$ BPA exposure. For example, the SOD, POD, CAT activities of $\mathrm{sp}(\mathrm{AB}-\mathrm{A})$ and $\mathrm{sp}(\mathrm{AB}-\mathrm{B})$, which formed $s p(A B)$, were significantly increased by a maximum of 13.63 and $14.35 \%, 32.68$ and $28.00 \%$, 31.03 and $71.98 \%$, compared with single species control(sp(A), sp(B)), respectively. Meanwhile the SOD, $P O D, C A T$ activities of $s p(A B C-A), s p(A B C-B)$ and $s p(A B C-C)$, which three plant species compositions formed $\mathrm{sp}(\mathrm{ABC})$, were significantly increased by a maximum of $12.91,13.72$ and $40.16 \%, 36.08,29.57$ and $45.21 \%, 34.53,64.01$ and $77.22 \%$, compared to single species control (sp(A), sp(B), sp(C)), respectively. These observations suggest that SOD, POD and CAT activities were further enhanced by mixed-hydroponic culture groups. This result indicated that antioxidant enzymes activities further effectively eliminated ROS to increase biomass and inhibit chlorophyll degradation of by mixedhydroponic culture groups.

\subsection{Effects of BPA on the content of antioxidant substances}

Ascorbic acid (AsA) has antioxidant functions, which is an effective scavenger for the hydroxyl radicals and superoxide (Li et al., 2020). Glutathione (GSH) is a key antioxidant copiously distributed in plants and animals (Ma et al., 2019, Ahammed et al., 2020). GSH is a low-molecular-weight thiol, which can directly remove ROS (Geu-Flores et al., 2011). At the same time, GSH is also involved in the detoxification of 
xenobiotics (Ahammed et al., 2020). Free proline (Pro) regulates cell membranes osmosis and responses to salinity, drought and other osmotic environmental stresses (Stein et al., 2011). Figure 3 depicts the effects of BPA on antioxidant substances in all large aquatic plants leaves. With increase the concentration of BPA, the ASA, GSH and Pro contents were increased in leaves. This result indicated that BPA stress induced an increase in antioxidant substances contents, which effectively eliminated ROS and reduced BPA contents and mediated osmotic adjustment in leaves. The ASA, GSH and Pro contents of the single species of $s p(A B), s p(A C), s p(B C)$ (without $G S H$ ) and $s p(A B C)$ cultured groups were significantly increased from $5 \mathrm{mg} \mathrm{L}^{-1}$ to $10 \mathrm{mg} \mathrm{L}^{-1} \mathrm{BPA}$, as compared to single species control $(\operatorname{sp}(A)$, $s p(B), s p(C)$ ), respectively. For example, the ASA, GSH, Pro contents of $s p(A B-A)$ and $s p(A B-B)$, which formed $s p(A B)$, were significantly increased by a maximum of 44.09 and $54.35 \%, 16.43$ and $13.11 \%$, 24.43 and $76.22 \%$, compared with single species control $(\mathrm{sp}(\mathrm{A}), \mathrm{sp}(\mathrm{B}))$, respectively. Meanwhile the ASA, GSH, Pro contents of $s p(A B C-A), s p(A B C-B)$ and $s p(A B C-C)$, which three plant species compositions formed $\mathrm{sp}(\mathrm{ABC})$, were significantly increased by a maximum of $54.12,53.89$ and $40.52 \%, 16.03,15.07$ and $12.53 \%, 28.16,73.67$ and $50.99 \%$, compared to single species control $(\operatorname{sp}(A), \operatorname{sp}(B), s p(C))$, respectively. These observations indicated that the ASA, GSH and Pro contents were further enhanced by mixed-hydroponic culture groups. These results suggest that antioxidant substances contents further effectively eliminated ROS reduced BPA contents and mediated osmotic adjustment for protecting normal physiological functions by mixed-hydroponic culture groups.

\subsection{Effect of BPA dosage on detoxification enzyme activity}

NADPH-cytochrome P450 reductase (CPR) is part of cytochrome P450s system, which transfers the reduced xenobiotics from NADPH to the cytochrome P450 (Chen et al., 2021). glutathione S-transferase (GST)and glycosyltransferase (GT) catalyzed conjugation of toxicants with GSH and sugar, respectively, and the complex were further delivered to subcellular apartment for catabolism (Zhang et al., 2017, Chen et al., 2021). Figure 4 illustrates the effects of BPA dosage on CPR, GST, GT activities and BPA contents in seven cultured groups of the single species seedlings leaves. Previous studies show that BPA was catalyzed the hydroxylation, epoxidation by cytochrome P450s system in phase I (Hamada et al., 2002, Sasaki et al., 2005, Gabriel et al., 2007). In phase II, BPA or BPA- hydroxylated was catalyzed synthesis reactions with GSH and sugar by GST and GT (Nakajima et al., 2002, Nakajima et al., 2004, Kanwar et al., 2020). Hence, the activities of CPR, GST, GT and BPA contents in leaves were increased with increasing BPA dosage, implying that BPA-degraded and residual BPA content were closely related to the enhanced plant detoxification of the enzymes. The CPR, GST and GT activities of all the single species of $s p(A B)$, $s p(A C), s p(B C)$ (only in $1.5 \mathrm{mg} \mathrm{L}^{-1} \mathrm{BPA}$ ) and $\mathrm{sp}(\mathrm{ABC})$ cultured groups were significantly increased from $1.5 \mathrm{mg} \mathrm{L}^{-1}$ to $10 \mathrm{mg} \mathrm{L}^{-1} \mathrm{BPA}$, respectively as compared to single species control $(\operatorname{sp}(A), \operatorname{sp}(B), s p(C))$, respectively. For example, the CPR, GST, GT activities of $s p(A B-A)$ and $s p(A B-B)$, which formed $s p(A B)$, were significantly increased by a maximum of 34.32 and $59.16 \%, 22.88$ and $15.66 \%, 65.51$ and $55.79 \%$, compared with single species control ( $(\mathrm{p}(\mathrm{A}), \mathrm{sp}(\mathrm{B}))$, respectively. Meanwhile the $\mathrm{CPR}, \mathrm{GST}, \mathrm{GT}$ activities of $s p(A B C-A), s p(A B C-B)$ and $s p(A B C-C)$, which three plant species compositions formed $s p(A B C)$, were 
significantly increased by a maximum of $35.39,75.38$ and $74.98 \%, 21.55,16.04$ and $33.41 \%, 69.47,64.73$ and $53.40 \%$, compared to single species control, respectively.

We also measured BPA contents in leaves. The BPA contents of all the single species of $s p(A B), s p(A C)$ and $\mathrm{sp}(\mathrm{ABC})$ cultured groups were significantly decreased from $1.5 \mathrm{mg} \mathrm{L}^{-1}$ to $10 \mathrm{mg} \mathrm{L}^{-1} \mathrm{BPA}$, respectively as compared to single species control $(s p(A), s p(B), s p(C))$, respectively. For example, the $s p(A B-A), s p(A B-B) \square s p(A C-A), s p(A C-C), s p(A B C-A), s p(A B C-B)$ and $s p(A B C-C)$, which formed $s p(A B), s p(A C)$ and $\operatorname{sp}(A B C)$ cultured groups, were significantly decreased by a maximum of $28.38,12.61,25.82,24.14$, $33.30,15.20$ and $30.33 \%$, compared with single species control $(s p(A), s p(B))$, respectively. These results suggest that BPA contents were further effectively reduced by mixed-hydroponic culture groups in leaves.

\section{Conclusions}

In conclusion, we found that BPA can be harmful to Phragmites australis(A), Typha latifolia(B) and Arundo donax $(\mathrm{C})$ through the induction oxidative stress in leaves, which eventually inhibited biomass production and chlorophyll content. However, the mixed-hydroponic cultures ( $s p(A B), s p(A B C)$ ) alleviate toxicological effects of BPA. This conclusion is supported by a proposed model depicting of the plant species compositions (Fig. 5). Firstly, BPA contents were further reduced by biotransformation and degradation of detoxification enzymes and biological Fenton reaction, Haber-Weiss reaction in the mixedhydroponic cultures ( $\mathrm{sp}(\mathrm{AB}), \mathrm{sp}(\mathrm{ABC})$ ). . BPA induced oxidative stress ability was severely weakened. Secondly, ROS levels which were produced by oxidative stress of BPA were further lowered by antioxidant enzymes and antioxidant substances content in the mixed-hydroponic cultures ( $\mathrm{sp}(A B), \mathrm{sp}(\mathrm{ABC})$ ). Thirdly, biomass production reduction and chlorophyll degradation were relieved due to the reduction of ROS levels in the mixed-hydroponic cultures ( $\mathrm{sp}(\mathrm{AB}), \mathrm{sp}(\mathrm{ABC})$ ). These results have already illustrated that reasonable plant richness and sort play an vital part in alleviating BPA stress. This study gives valuable data on how to create artificial floating island and constructed wetland with tall working BPA expulsion.

\section{Declarations}

\section{Author information}

Affiliations

College of Environmental Science and Engineering, Ocean University of China, Qingdao, 266100, China Xianguang Nie \& Lin Wang

\section{Contributions}

All authors contributed to the study conception and design. Material preparation, data collection, and analysis were performed by Xianguang Nie. The first draft of the manuscript was written by Xianguang 
Nie; all authors commented on previous versions of the manuscript. All authors read and approved the final manuscript.

\section{Corresponding authors}

Correspondence to Lin Wang.

\section{Funding}

This work was supported by the Program of China Scholarship Council (No. 20120370391) and the National Key Research and Development Program of China (NO. 2018YFC0408000, 2018YFC0408004).

\section{Ethics declarations}

Ethics approval and consent to participate

Not applicable.

\section{Consent for publication}

Not applicable.

\section{Competing interests}

The authors declare no competing interests.

\section{Availability of data and materials}

The datasets used and analyzed during the current study are available from the corresponding author on reasonable request.

\section{References}

Ahammed G. J., Wang Y., Mao Q., Wu M., Yan Y., Ren J., Wang X., Liu A., Chen S., (2020) Dopamine alleviates bisphenol A-induced phytotoxicity by enhancing antioxidant and detoxification potential in cucumber. Environ Pollut. 259. 113957. doi:10.1016/j.envpol.2020.113957

Ahammed G. J., Wang Y. Q., Mao Q., Wu M. J., Yan Y. R., Ren J. J., Wang X. J., Liu A. R., Chen S. C., (2020) Dopamine alleviates bisphenol A-induced phytotoxicity by enhancing antioxidant and detoxification potential in cucumber. Environ Pollut. 259. doi:ARTN 113957 10.1016/j.envpol.2020.113957

Ali I., Liu B. H., Farooq M. A., Islam F., Azizullah A., Yu C. Y., Su W., Gan Y. B., (2016) Toxicological effects of bisphenol $A$ on growth and antioxidant defense system in Oryza saliva as revealed by ultrastructure analysis. Ecotox Environ Safe. 124. 277-284. doi:10.1016/j.ecoenv.2015.10.027 
Ali I., Jan M., Wakeel A., Azizullah A., Liu B. H., Islam F., Ali A., Daud M. K., Liu Y. H., Gan Y. B., (2017) Biochemical responses and ultrastructural changes in ethylene insensitive mutants of Arabidopsis thialiana subjected to bisphenol A exposure. Ecotox Environ Safe. 144. 62-71.

doi:10.1016/j.ecoenv.2017.06.015

Arnon D. I., (1949) Copper enzymes in isolated chloroplasts. polyphenoloxidase in beta vulgaris. Plant Physiol. 24. 1-15. doi:10.1104/pp.24.1.1

Bartha B., Huber C., Schroder P., (2014) Uptake and metabolism of diclofenac in Typha latifolia - How plants cope with human pharmaceutical pollution. Plant Sci. 227. 12-20.

doi:10.1016/j.plantsci.2014.06.001

Biczak R., Snioszek M., Telesinski A., Pawlowska B., (2017) Growth inhibition and efficiency of the antioxidant system in spring barley and common radish grown on soil polluted ionic liquids with iodide anions. Ecotox Environ Safe. 139. 463-471. doi:10.1016/j.ecoenv.2017.02.016

Bonanno G., (2013) Comparative performance of trace element bioaccumulation and biomonitoring in the plant species Typha domingensis, Phragmites australis and Arundo donax. Ecotox Environ Safe. 97. 124-130. doi:10.1016/j.ecoenv.2013.07.017

Calheiros C. S. C., Rangel A. O. S. S., Castro P. M. L., (2009) Treatment of industrial wastewater with twostage constructed wetlands planted with Typha latifolia and Phragmites australis. Bioresource Technol. 100. 3205-3213. doi:10.1016/j.biortech.2009.02.017

Cao C., Huang J., Guo Y., Yan C. N., Xiao J., Ma Y. X., Liu J. L., Guan W. Z., (2019) Long-term effects of environmentally relevant concentration of Ag nanoparticles on the pollutant removal and spatial distribution of silver in constructed wetlands with Cyperus alternifolius and Arundo donax. Environ Pollut. 252. 931-940. doi:10.1016/j.envpol.2019.05.144

Chen Z. J., Lv Y., Zhai X. Y., Yang H., (2021) Comprehensive analyses of degradative enzymes associated with mesotrione-degraded process in rice for declining environmental risks. Sci Total Environ. 758. 143618. doi:10.1016/j.scitotenv.2020.143618

Czarnocka W., Karpinski S., (2018) Friend or foe? Reactive oxygen species production, scavenging and signaling in plant response to environmental stresses. Free Radical Bio Med. 122. 4-20.

doi:10.1016/j.freeradbiomed.2018.01.011

Devos C. H. R., Vonk M. J., Vooijs R., Schat H., (1992) Glutathione Depletion Due to Copper-Induced Phytochelatin Synthesis Causes Oxidative Stress in Silene-Cucubalus. Plant Physiol. 98. 853-858. doi:DOI 10.1104/pp.98.3.853

Du S. T., Liu Y., Zhang P., Liu H. J., Zhang X. Q., Zhang R. R., (2015) Atmospheric application of trace amounts of nitric oxide enhances tolerance to salt stress and improves nutritional quality in spinach 
(Spinacia oleracea L.). Food Chem. 173. 905-911. doi:10.1016/j.foodchem.2014.10.115

Dumitrascu M. C., Mares C., Petca R. C., Sandru F., Popescu R. I., Mehedintu C., Petca A., (2020) Carcinogenic effects of bisphenol A in breast and ovarian cancers. Oncol Lett. 20. doi:ARTN 282 10.3892/ol.2020.12145

Elstner E. F., Heupel A., (1976) Inhibition of nitrite formation from hydroxylammoniumchloride: a simple assay for superoxide dismutase. Anal Biochem. 70. 616-620. doi:10.1016/0003-2697(76)90488-7

Ferrara G., Loffredo E., Senesi N., (2006) Phytotoxic, clastogenic and bioaccumulation effects of the environmental endocrine disruptor bisphenol A in various crops grown hydroponically. Planta. 223. 910916. doi:10.1007/s00425-005-0147-2

Fornara D. A., Tilman D., (2008) Plant functional composition influences rates of soil carbon and nitrogen accumulation. J Ecol. 96. 314-322. doi:10.1111/j.1365-2745.2007.01345.x

Fornara D. A., Tilman D., (2009) Ecological mechanisms associated with the positive diversity-productivity relationship in an N-limited grassland. Ecology. 90. 408-418. doi:Doi 10.1890/08-0325.1

Fuerst E. P., Irzyk G. P., Miller K. D., (1993) Partial Characterization of Glutathione-S-Transferase Isozymes Induced by the Herbicide Safener Benoxacor in Maize. Plant Physiol. 102. 795-802. doi:DOI 10.1104/pp.102.3.795

Gabriel F. L. P., Cyris M., Giger W., Kohler H. P. E., (2007) ipso-substitution: A general biochemical and biodegradation mechanism to cleave alpha-quaternary alkylphenols and bisphenol A. Chem Biodivers. 4 . 2123-2137. doi:DOI 10.1002/cbdv.200790170

Gattullo C. E., Bahrs H., Steinberg C. E. W., Loffredo E., (2012) Removal of bisphenol A by the freshwater green alga Monoraphidium braunii and the role of natural organic matter. Sci Total Environ. 416. 501-506. doi:10.1016/j.scitotenv.2011.11.033

Geu-Flores F., Moldrup M. E., Bottcher C., Olsen C. E., Scheel D., Halkier B. A., (2011) Cytosolic gammaGlutamyl Peptidases Process Glutathione Conjugates in the Biosynthesis of Glucosinolates and Camalexin in Arabidopsis. Plant Cell. 23. 2456-2469. doi:10.1105/tpc.111.083998

Gross K., (2008) Positive interactions among competitors can produce species-rich communities. Ecol Lett. 11. 929-936. doi:10.1111/j.1461-0248.2008.01204.x

Guengerich F. P., Martin M. V., Sohl C. D., Cheng Q., (2009) Measurement of cytochrome P450 and NADPHcytochrome P450 reductase. Nat Protoc. 4. 1245-1251. doi:10.1038/nprot.2009.121

Guida M., Troisi J., Ciccone C., Granozio G., Cosimato C., Sardo A. D., Ferrara C., Guida M., Nappi C., Zullo F., Di Carlo C., (2015) Bisphenol A and congenital developmental defects in humans. Mutat Res-Fund Mol M. 774. 33-39. doi:10.1016/j.mrfmmm.2015.02.007 
Halliwell B., (1999) Oxygen and nitrogen are pro-carcinogens, Damage to DNA by reactive oxygen, chlorine and nitrogen species: measurement, mechanism and the effects of nutrition. Mutat Res-Gen Tox En. 443. 37-52. doi:Doi 10.1016/S1383-5742(99)00009-5

Hamad M. T. M. H., (2020) Comparative study on the performance of Typha latifolia and Cyperus Papyrus on the removal of heavy metals and enteric bacteria from wastewater by surface constructed wetlands. Chemosphere. 260. doi:ARTN 127551 10.1016/j.chemosphere.2020.127551

Hamada H., Tomi R., Asada Y., Furuya T., (2002) Phytoremediation of bisphenol A by cultured suspension cells of Eucalyptus perriniana-regioselective hydroxylation and glycosylation. Tetrahedron Lett. 43. 40874089. doi:Pii S0040-4039(02)00647-0 Doi 10.1016/S0040-4039(02)00647-0

He Y. J., Langenhoff A. A. M., Sutton N. B., Rijnaarts H. H. M., Blokland M. H., Chen F. R., Huber C., Schroder P., (2017) Metabolism of Ibuprofen by Phragmites australis: Uptake and Phytodegradation. Environ Sci Technol. 51. 4576-4584. doi:10.1021/acs.est.7b00458

Heath R. L., Packer L., (1965) Effect of light on lipid peroxidation in chloroplasts. Biochem Bioph Res Co. 19. 716-720. doi:10.1016/0006-291x(65)90316-5

Im J., Loffler F. E., (2016) Fate of Bisphenol A in Terrestrial and Aquatic Environments. Environ Sci Technol. 50. 8403-8416. doi:10.1021/acs.est.6b00877

Inagaki Y., Cong V. H., Sakakibara Y., (2016) Identification and application of Phyto-Fenton reactions. Chemosphere. 144. 1443-1450. doi:10.1016/j.chemosphere.2015.10.039

Jiang M. Y., Zhang J. H., (2001) Effect of abscisic acid on active oxygen species, antioxidative defence system and oxidative damage in leaves of maize seedlings. Plant Cell Physiol. 42. 1265-1273. doi:DOI 10.1093/pcp/pce162

Jiao L. Y., Wang L. H., Qiu Z. Y., Wang Q. Q., Zhou Q., Huang X. H., (2015) Effects of bisphenol A on chlorophyll synthesis in soybean seedlings. Environ Sci Pollut R. 22. 5877-5886. doi:10.1007/s11356014-3764-0

Jiao L. Y., Ding H. Z., Wang L. H., Zhou Q., Huang X. H., (2017) Bisphenol A effects on the chlorophyll contents in soybean at different growth stages. Environ Pollut. 223. 426-434.

doi:10.1016/j.envpol.2017.01.042

Kanwar M. K., Xie D., Yang C., Ahammed G. J., Qi Z., Hasan M. K., Reiter R. J., Yu J. Q., Zhou J., (2020) Melatonin promotes metabolism of bisphenol A by enhancing glutathione-dependent detoxification in Solanum lycopersicum L. J Hazard Mater. 388. 121727. doi:10.1016/j.jhazmat.2019.121727

Kim D., Kwak J. I., An Y. J., (2018) Effects of bisphenol A in soil on growth, photosynthesis activity, and genistein levels in crop plants (Vigna radiata). Chemosphere. 209. 875-882. doi:10.1016/j.

chemosphere.2018.06.146

Page 15/27 
Lee S., Liao C., Song G. J., Ra K., Kannan K., Moon H. B., (2015) Emission of bisphenol analogues including bisphenol $\mathrm{A}$ and bisphenol $\mathrm{F}$ from wastewater treatment plants in Korea. Chemosphere. 119. 1000-1006. doi:10.1016/j. chemosphere.2014.09.011

Li H., Liu J. X., Wang Y., Zhuang J., (2020) The ascorbate peroxidase 1 regulates ascorbic acid metabolism in fresh-cut leaves of tea plant during postharvest storage under light/dark conditions. Plant Sci. 296. doi:ARTN 110500

\subsection{6/j.plantsci.2020.110500}

Li R., Liu Y., Chen G. Z., Tam N. F. Y., Shin P. K. S., Cheung S. G., Luan T. G., (2008) Physiological responses of the alga Cyclotella caspia to bisphenol A exposure. Bot Mar. 51. 360-369. doi:10.1515/Bot.2008.050

Li X., Wang L., Wang S., Yang Q., Zhou Q., Huang X., (2018) A preliminary analysis of the effects of bisphenol $A$ on the plant root growth via changes in endogenous plant hormones. Ecotoxicol Environ Saf. 150. 152-158. doi:10.1016/j.ecoenv.2017.12.031

Li X. Y., Wang L. H., Shen F., Zhou Q., Huang X. H., (2018) Impacts of exogenous pollutant bisphenol A on characteristics of soybeans. Ecotox Environ Safe. 157. 463-471. doi:10.1016/j.ecoenv.2018.04.013

Liu J., Wang Y. F., Jiang B. Q., Wang L. H., Chen J. Q., Guo H. Y., Ji R., (2013) Degradation, Metabolism, and Bound-Residue Formation and Release of Tetrabromobisphenol A in Soil during Sequential AnoxicOxic Incubation. Environ Sci Technol. 47. 8348-8354. doi:10.1021/es4014322

Loffredo E., Gattullo C. E., Traversa A., Senesi N., (2010) Potential of various herbaceous species to remove the endocrine disruptor bisphenol A from aqueous media. Chemosphere. 80. 1274-1280. doi:10.1016/j.chemosphere.2010.06.054

M. Dogan O. Yumrutas, S.D. SaygiDeger, M. Korkunc, O. Gulnaz, A. Sokmen, (2010) Effects of bisphenol A and tetrabromobisphenol A on chickpea roots in germination stage. Am.-Eurasian J. Agric. Environ. Sci.

Ma Y., Liu H. H., Wu J. X., Yuan L., Wang Y. Q., Du X. D., Wang R., Marwa P. W., Petlulu P., Chen X. H., Zhang H. Z., (2019) The adverse health effects of bisphenol A and related toxicity mechanisms. Environ Res. 176. doi:ARTN 108575 10.1016/j.envres.2019.108575

Maehly A. C., Chance B., (1954) The assay of catalases and peroxidases. Methods of biochemical analysis. 1. 357-424.

Maher B., English K., Norman R., Sly P., Davies P., (2016) Prenatal exposure to the plasticizer bisphenol A (BPA) and adverse birth outcomes in human epidemiological studies. Clin Endocrinol. 84. 12-12.

Martinez M. A., Blanco J., Rovira J., Kumara V., Domingo J. L., Schuhmacher M., (2020) Bisphenol A analogues (BPS and BPF) present a greater obesogenic capacity in 3T3-L1 cell line. Food Chem Toxicol. 140. doi:ARTN 111298 10.1016/j.fct.2020.111298 
Mattila H., Khorobrykh S., Havurinne V., Tyystjarvi E., (2015) Reactive oxygen species: Reactions and detection from photosynthetic tissues. J Photoch Photobio B. 152. 176-214.

doi:10.1016/j.jphotobiol.2015.10.001

Nakajima N., Ohshima Y., Serizawa S., Kouda T., Edmonds J. S., Shiraishi F., Aono M., Kubo A., Tamaoki M., Saji H., Morita M., (2002) Processing of bisphenol A by plant tissues: Glucosylation by cultured BY-2 cells and Glucosylation/translocation by plants of Nicotiana tabacum. Plant Cell Physiol. 43. 1036-1042. doi:DOI 10.1093/pcp/pcf130

Nakajima N., Ohshima Y., Serizawa S., Kouda T., Edmonds J. S., Shiraishi F., Aono M., Kubo A., Tamaoki M., Saji H., Morita M., (2002) Processing of bisphenol A by plant tissues: glucosylation by cultured BY-2 cells and glucosylation/translocation by plants of Nicotiana tabacum. Plant Cell Physiol. 43. 1036-1042. doi:10.1093/pcp/pcf130

Nakajima N., Oshima Y., Edmonds J. S., Morita M., (2004) Glycosylation of bisphenol A by tobacco BY-2 cells. Phytochemistry. 65. 1383-1387. doi:10.1016/j.phytochem.2004.02.027

Nakamura S., Tezuka Y., Ushiyama A., Kawashima C., Kitagawara Y., Takahashi K., Ohta S., Mashino T., (2011) Ipso substitution of bisphenol A catalyzed by microsomal cytochrome P450 and enhancement of estrogenic activity. Toxicol Lett. 203. 92-95. doi:10.1016/j.toxlet.2011.03.010

Noureddin M. I., Furumoto T., Ishida Y., Fukui H., (2004) Absorption and metabolism of bisphenol A, a possible endocrine disruptor, in the aquatic edible plant, water convolvulus (Ipomoea aquatica). Biosci Biotech Bioch. 68. 1398-1402. doi:DOI 10.1271/bbb.68.1398

Pandey P., Srivastava R. K., Rajpoot R., Rani A., Pandey A. K., Dubey R. S., (2016) Water deficit and aluminum interactive effects on generation of reactive oxygen species and responses of antioxidative enzymes in the seedlings of two rice cultivars differing in stress tolerance. Environ Sci Pollut R. 23. 15161528. doi:10.1007/s11356-015-5392-8

Patterson B. D., MacRae E. A., Ferguson I. B., (1984) Estimation of hydrogen peroxide in plant extracts using titanium(IV). Anal Biochem. 139. 487-492. doi:10.1016/0003-2697(84)90039-3

Pawlowska B., Feder-Kubis J., Telesinski A., Biczak R., (2019) Biochemical Responses of Wheat Seedlings on the Introduction of Selected Chiral Ionic Liquids to the Soils. J Agr Food Chem. 67. 3086-3095. doi:10.1021/acs.jafc.8b05517

Qiu Z. Y., Wang L. H., Zhou Q., (2013) Effects of bisphenol A on growth, photosynthesis and chlorophyll fluorescence in above-ground organs of soybean seedlings. Chemosphere. 90. 1274-1280. doi:10.1016/j.chemosPhere.2012.09.085

Reis A. R., Sakakibara Y., (2012) Enzymatic degradation of endocrine-disrupting chemicals in aquatic plants and relations to biological Fenton reaction. Water Sci Technol. 66. 775-782. 
Reis A. R., Tabei K., Sakakibara Y., (2014) Oxidation mechanism and overall removal rates of endocrine disrupting chemicals by aquatic plants. J Hazard Mater. 265. 79-88. doi:10.1016/j.jhazmat.2013.11.042

Sasaki M., Tsuchido T., Matsumura Y., (2008) Molecular cloning and characterization of cytochrome P450 and ferredoxin genes involved in bisphenol A degradation in Sphingomonas bisphenolicum strain A01. J Appl Microbiol. 105. 1158-1169. doi:10.1111/j.1365-2672.2008.03843.x

Sasaki M., Akahira A., Oshiman K. I., Tsuchido T., Matsumura Y., (2005) Purification of cytochrome P450 and ferredoxin, involved in bisphenol A degradation, from Sphingomonas sp strain A01. Appl Environ Microb. 71. 8024-8030. doi:10.1128/Aem.71.12.8024-8030.2005

Shimoda K., Hamada H., (2009) Bioremediation of Bisphenol A and Benzophenone by Glycosylation with Immobilized Marine Microalga Pavlova sp. Environ Health Insights. 3. 89-94. doi:10.4137/ehi.s2758

Singh N., Ma L. Q., Srivastava M., Rathinasabapathi B., (2006) Metabolic adaptations to arsenic-induced oxidative stress in Pteris vittata $L$ and Pteris ensiformis L. Plant Sci. 170. 274-282.

doi:10.1016/j.plantsci.2005.08.013

Staples C. A., Dorn P. B., Klecka G. M., O'Block S. T., Harris L. R., (1998) A review of the environmental fate, effects, and exposures of bisphenol A. Chemosphere. 36. 2149-2173. doi:Doi 10.1016/S00456535(97)10133-3

Stein H., Honig A., Miller G., Erster O., Eilenberg H., Csonka L. N., Szabados L., Koncz C., Zilberstein A., (2011) Elevation of free proline and proline-rich protein levels by simultaneous manipulations of proline biosynthesis and degradation in plants. Plant Sci. 181. 140-150. doi:10.1016/j.plantsci.2011.04.013

Tan L. R., Lu Y. C., Zhang J. J., Luo F., Yang H., (2015) A collection of cytochrome P450 monooxygenase genes involved in modification and detoxification of herbicide atrazine in rice (Oryza sativa) plants. Ecotox Environ Safe. 119. 25-34. doi:10.1016/j.ecoenv.2015.04.035

Troll W., Lindsley J., (1955) A photometric method for the determination of proline. The Journal of biological chemistry. 215. 655-660.

Wang H., Jin M. K., Xu L. L., Xi H., Wang B. H., Du S. T., Liu H. J., Wen Y. Z., (2020) Effects of ketoprofen on rice seedlings: Insights from photosynthesis, antioxidative stress, gene expression patterns, and integrated biomarker response analysis. Environ Pollut. 263. doi:ARTN 114533

10.1016/j.envpol.2020.114533

Wang H., Jin M. K., Mao W. F., Chen C. J., Fu L. Y., Li Z., Du S. T., Liu H. J., (2020) Photosynthetic toxicity of non-steroidal anti-inflammatory drugs (NSAIDs) on green algae Scenedesmus obliquus. Sci Total Environ. 707. doi:ARTN 136176 
Wang I. J., Chen C. Y., Bornehag C. G., (2016) Bisphenol A exposure may increase the risk of development of atopic disorders in children. Int J Hyg Envir Heal. 219. 311-316. doi:10.1016/j.ijheh.2015.12.001

Wang Q. Q., Wang L. H., Han R. B., Yang L. Y., Zhou Q., Huang X. H., (2015) Effects of Bisphenol a on Antioxidant System in Soybean Seedling Roots. Environ Toxicol Chem. 34. 1127-1133.

doi:10.1002/etc.2904

Wang X., Luo B., Wang L., Zhao Y., Wang Q., Li D., Gu B., Min Y., Chang S. X., Ge Y., Chang J., (2020) Plant diversity improves the effluent quality and stability of floating constructed wetlands under increased ammonium/nitrate ratio in influent. J Environ Manage. 266. 110607.

doi:10.1016/j.jenvman.2020.110607

Wang X. P., Lim T. T., (2011) Effect of hexamethylenetetramine on the visible-light photocatalytic activity of C-N codoped TiO2 for bisphenol A degradation: evaluation of photocatalytic mechanism and solution toxicity. Appl Catal a-Gen. 399. 233-241. doi:10.1016/j.apcata.2011.04.002

Wang Y. H., Wang J. F., Zhao X. X., Song X. S., Gong J., (2016) The inhibition and adaptability of four wetland plant species to high concentration of ammonia wastewater and nitrogen removal efficiency in constructed wetlands. Bioresource Technol. 202. 198-205. doi:10.1016/j.biortech.2015.11.049

Wisniowska B., Linke S., Pirow R., Luch A., Tylutki Z., Polak S., (2020) Utilization of Physiologically Based Pharmacokinetic Modeling to Assess Dermal Uptake of Bisphenol A (BPA) and Its Skin and Systemic Exposure in Humans. Int J Toxicol. 39. 62-62.

Xiang R., Shi J. Q., Yu Y., Zhang H. B., Dong C. C., Yang Y. J., Wu Z. X., (2018) The Effect of Bisphenol A on Growth, Morphology, Lipid Peroxidation, Antioxidant Enzyme Activity, and PS II in Cylindrospermopsis raciborskii and Scenedesmus quadricauda. Arch Environ Con Tox. 74. 515-526. doi:10.1007/s00244-0170454-1

Xiao C. Y., Wang L. H., Hu D. D., Zhou Q., Huang X. H., (2019) Effects of exogenous bisphenol A on the function of mitochondria in root cells of soybean (Glycine max L.) seedlings. Chemosphere. 222. 619627. doi:10.1016/j.chemosphere.2019.01.195

Xiao C. Y., Wang L. H., Zhou Q., Huang X. H., (2020) Hazards of bisphenol A (BPA) exposure: A systematic review of plant toxicology studies. J Hazard Mater. 384. doi:ARTN 121488

10.1016/j.jhazmat.2019.121488

Xu C. P., Natarajan S., Sullivan J. H., (2008) Impact of solar ultraviolet-B radiation on the antioxidant defense system in soybean lines differing in flavonoid contents. Environ Exp Bot. 63. 39-48. doi:10.1016/j.envexpbot.2007.10.029 
Yamamoto T., Yasuhara A., Shiraishi H., Nakasugi O., (2001) Bisphenol A in hazardous waste landfill leachates. Chemosphere. 42. 415-418. doi:Doi 10.1016/S0045-6535(00)00079-5

Yu K., Yi S., Li B., Guo F., Peng X., Wang Z., Wu Y., Alvarez-Cohen L., Zhang T., (2019) An integrated metaomics approach reveals substrates involved in synergistic interactions in a bisphenol A (BPA)-degrading microbial community. Microbiome. 7. 16. doi:10.1186/s40168-019-0634-5

Zhang J. J., Gao S., Xu J. Y., Lu Y. C., Lu F. F., Ma L. Y., Su X. N., Yang H., (2017) Degrading and Phytoextracting Atrazine Residues in Rice (Oryza sativa) and Growth Media Intensified by a Phase II Mechanism Modulator. Environ Sci Technol. 51. 11258-11268. doi:10.1021/acs.est.7b02346

Zhang J. Z., Li X. Y., Zhou L., Wang L. H., Zhou Q., Huang X. H., (2016) Analysis of effects of a new environmental pollutant, bisphenol A, on antioxidant systems in soybean roots at different growth stages. Sci Rep-Uk. 6. doi:ARTN 23782 10.1038/srep23782

Zhang J. Z., Wang L. H., Zhou Q., Huang X. H., (2018) Reactive oxygen species initiate a protective response in plant roots to stress induced by environmental bisphenol A. Ecotox Environ Safe. 154. 197205. doi:10.1016/j.ecoenv.2018.02.020

Zheng Y. C., Wang X. C., Dzakpasu M., Zhao Y. Q., Ngo H. H., Guo W. S., Ge Y., Xiong J. Q., (2016) Effects of interspecific competition on the growth of macrophytes and nutrient removal in constructed wetlands: A comparative assessment of free water surface and horizontal subsurface flow systems. Bioresource Technol. 207. 134-141. doi:10.1016/j.biortech.2016.02.008

Zhu S. S., Huang X. C., Ho S. H., Wang L., Yang J. X., (2017) Effect of plant species compositions on performance of lab-scale constructed wetland through investigating photosynthesis and microbial communities. Bioresource Technol. 229. 196-203. doi:10.1016/j.biortech.2017.01.023

\section{Figures}



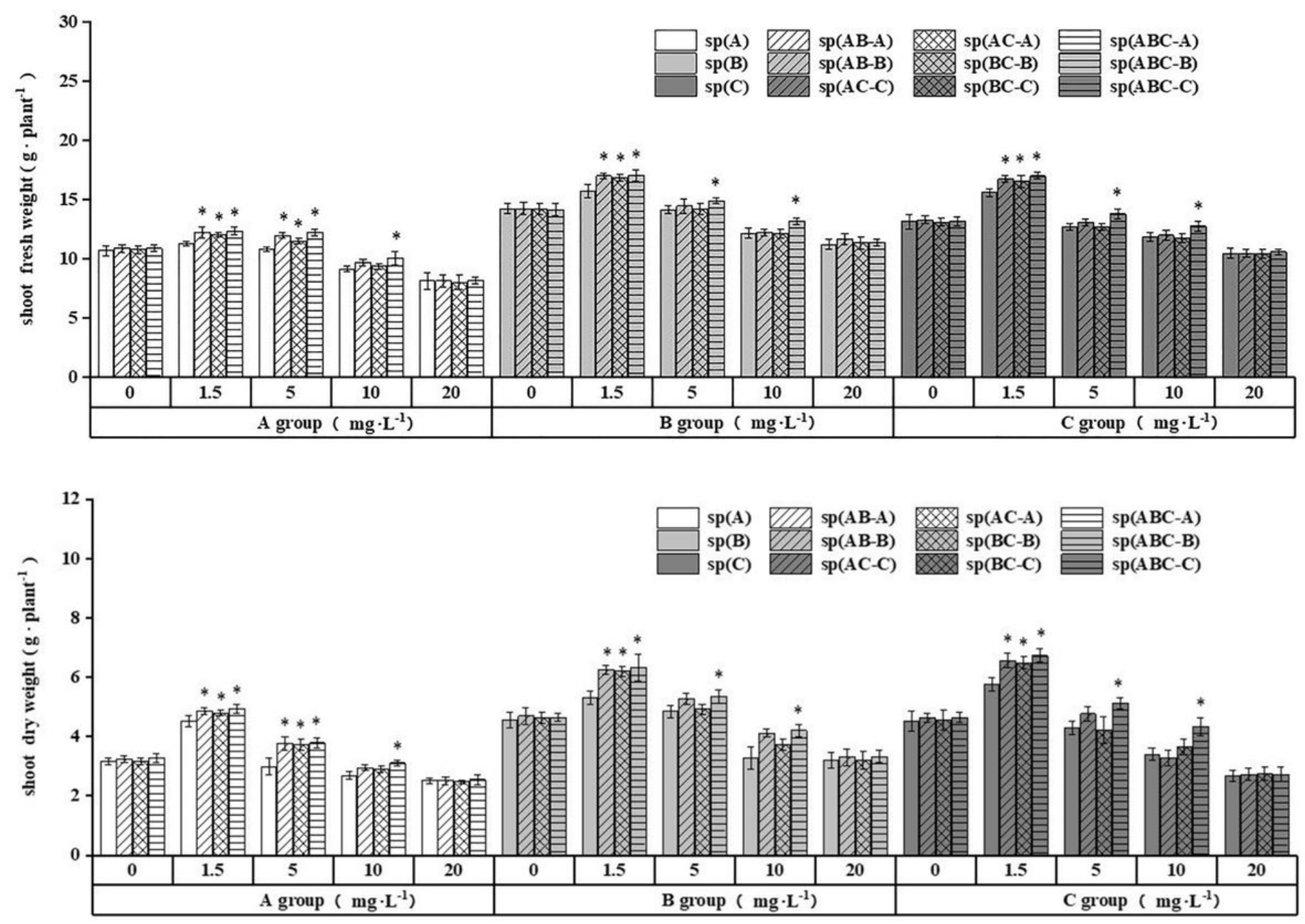

Figure 1

Effects of BPA on the shoots fresh and dry weight after ten days of exposure. The error bars indicate standard deviation $(n=3)$. The asterisk $(*)$ indicates significant differences $(p<0.05)$ with compared to single species control $(s p(A), s p(B), s p(C))$, respectively. 

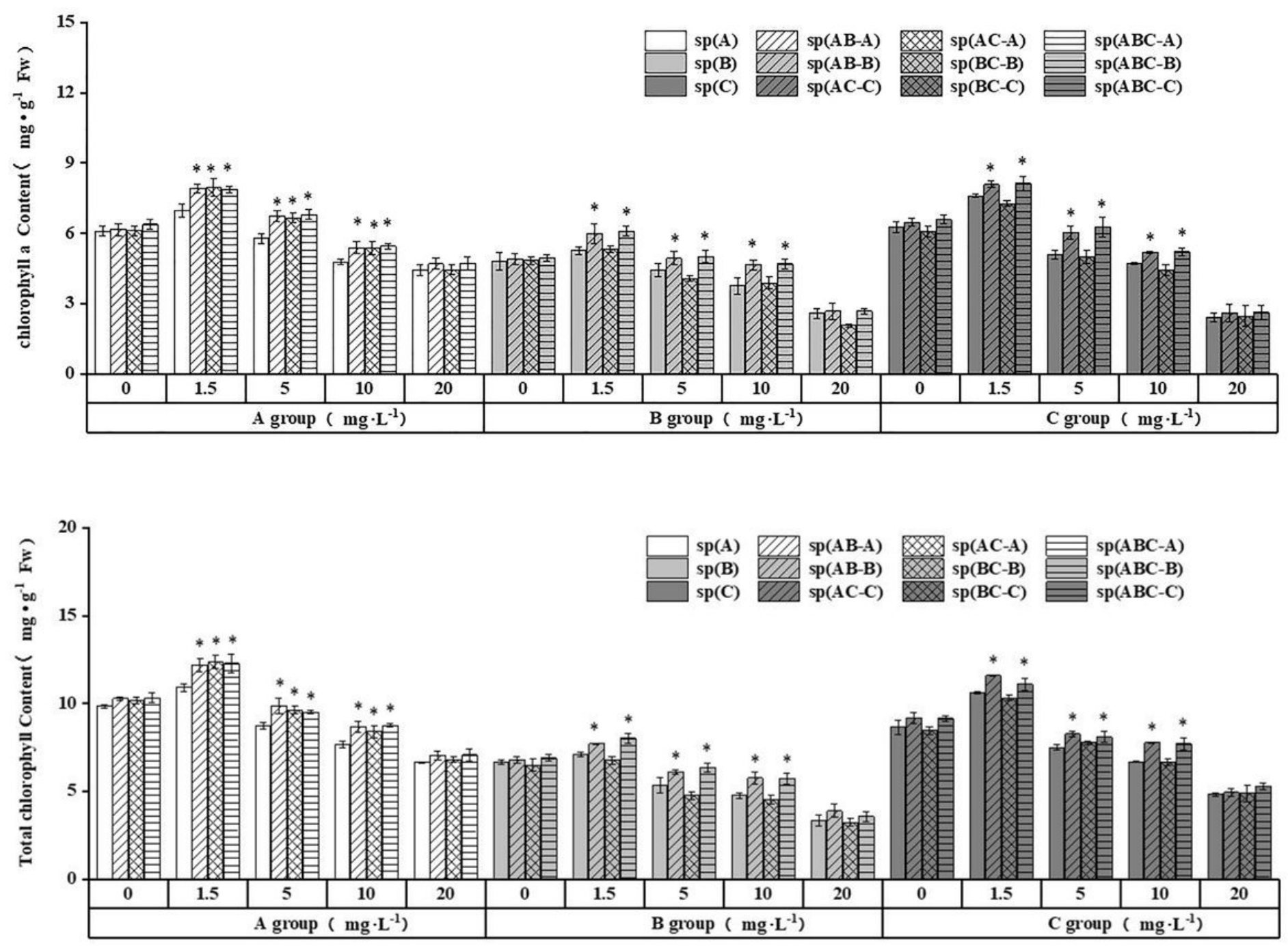

Figure 2

Effects of BPA on chlorophyll a and total chlorophyll content of leaves after ten days of exposure. The error bars indicate standard deviation $(n=3)$. The asterisk $(*)$ indicates significant differences $(p<0.05)$ with compared to single species control ( $s p(A), s p(B), s p(C))$, respectively. 

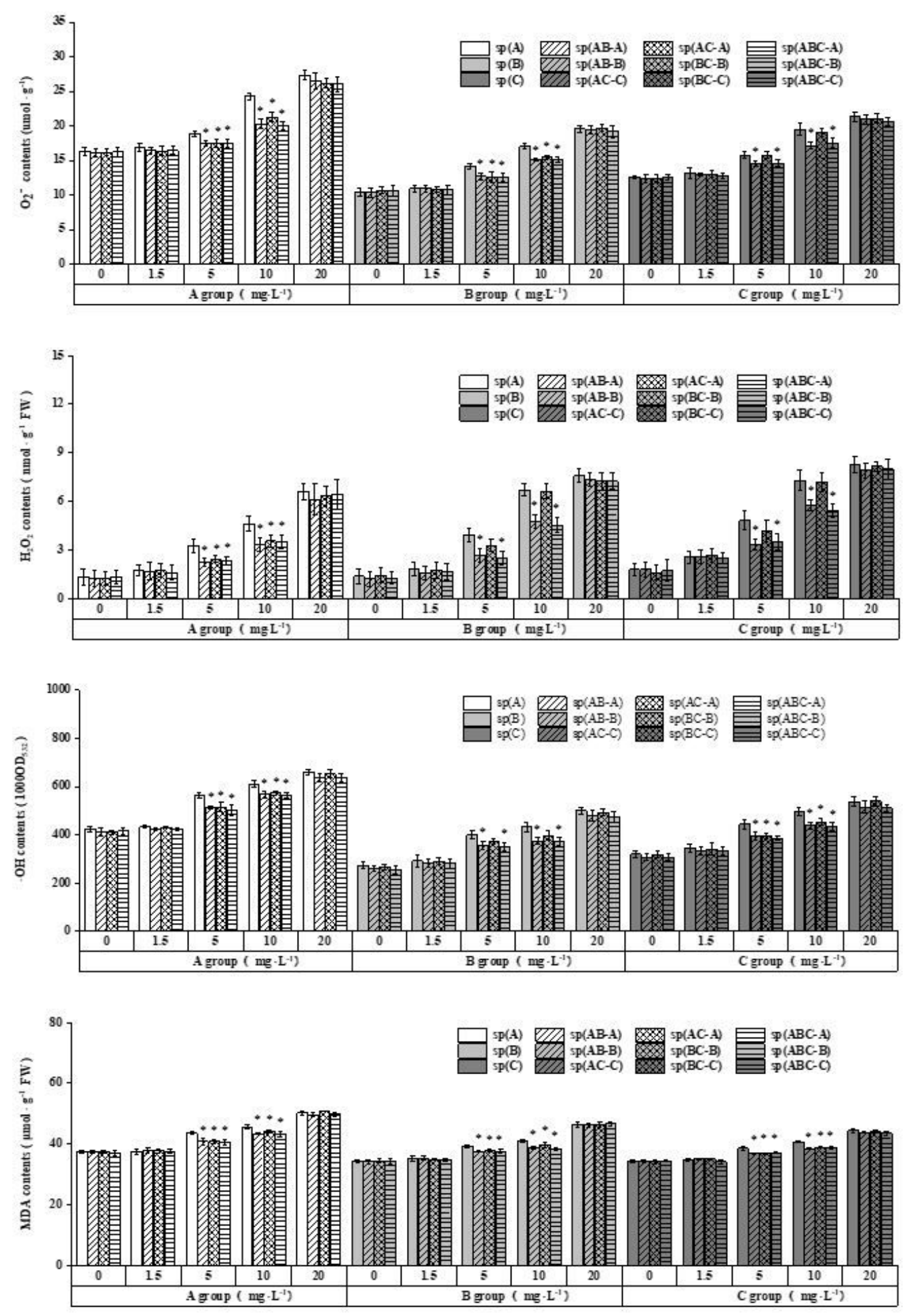

\section{Figure 3}

Effects of BPA on levels of $\mathrm{O} 2-, \mathrm{H} 2 \mathrm{O} 2, \cdot \mathrm{OH}$ and MDA content of leaves after ten days of exposure. The error bars indicate standard deviation $(n=3)$. The asterisk $(*)$ indicates significant differences $(p<0.05)$ with compared to single species control ( $\mathrm{sp}(\mathrm{A}), \mathrm{sp}(\mathrm{B}), \mathrm{sp}(\mathrm{C}))$, respectively. 

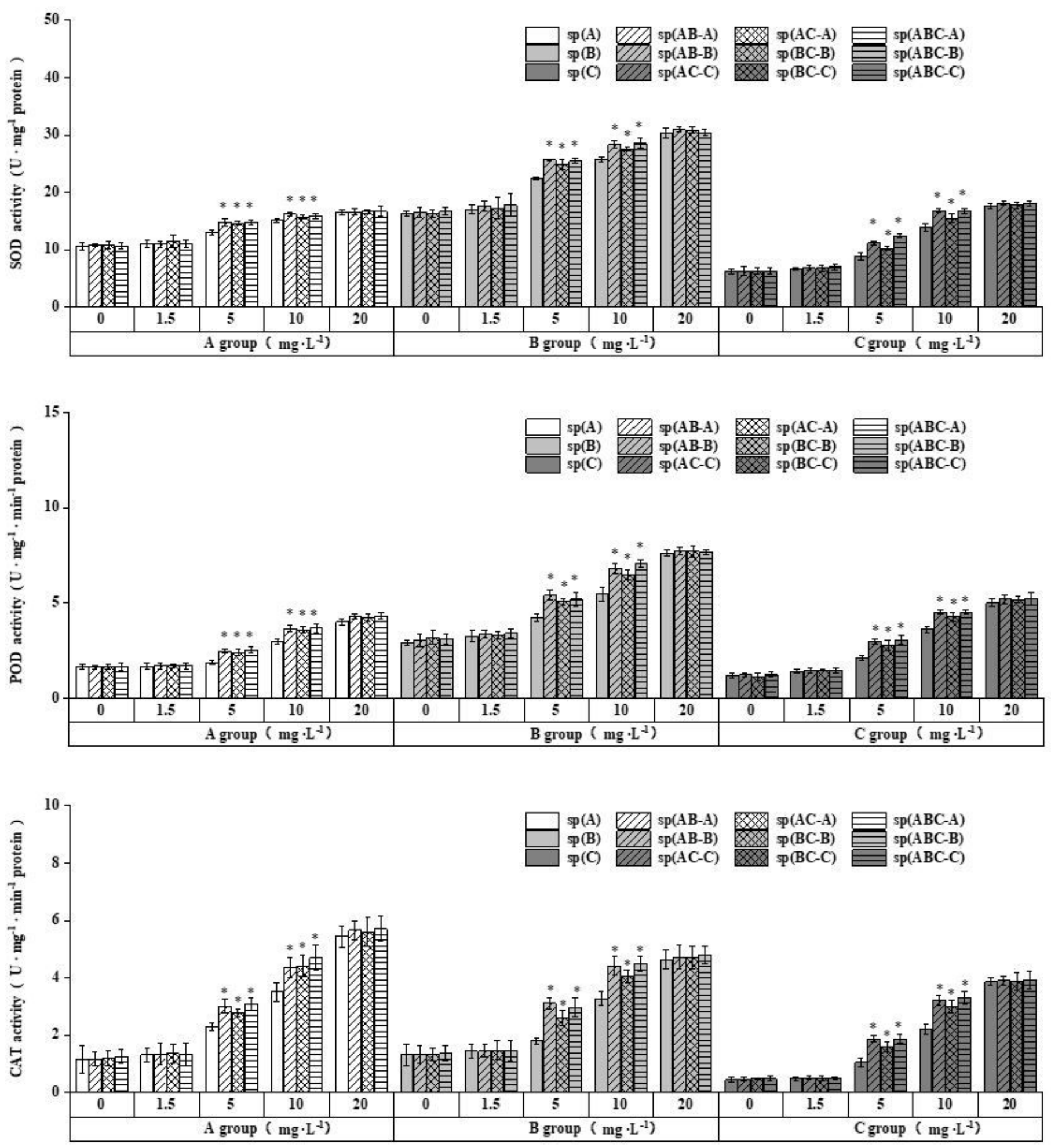

\section{Figure 4}

Effects of BPA on SOD, POD, and CAT activities of leaves after ten days of exposure. The error bars indicate standard deviation $(n=3)$. The asterisk $\left(^{*}\right)$ indicates significant differences $(p<0.05)$ with compared to single species control $(s p(A), s p(B), s p(C))$, respectively. 

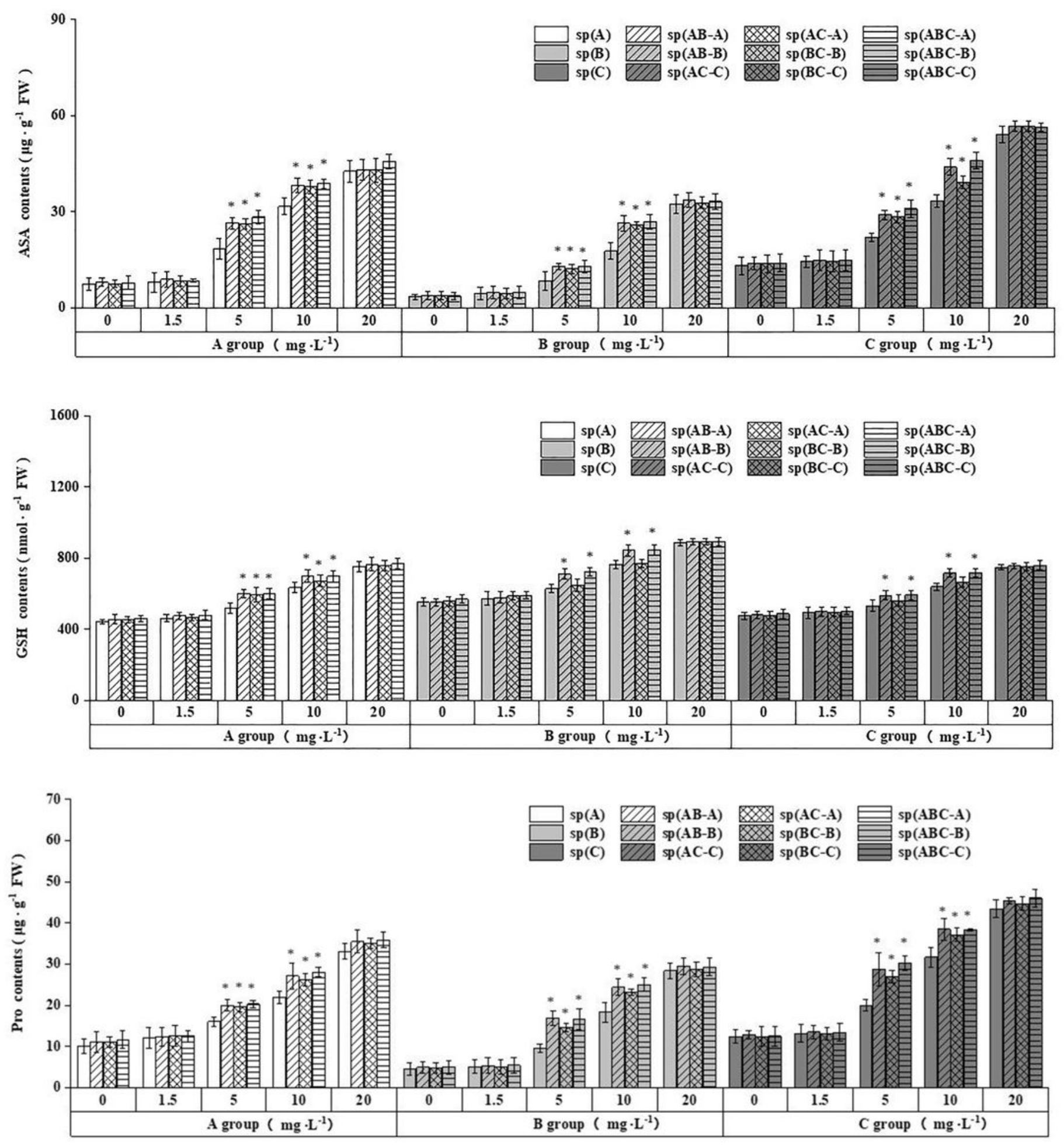

\section{Figure 5}

Effects of BPA on the ASA, GSH and Pro contents of leaves after ten days of exposure. The error bars indicate standard deviation $(n=3)$. The asterisk $\left(^{*}\right)$ indicates significant differences $(p<0.05)$ with compared to single species control $(s p(A), s p(B), s p(C))$, respectively. 

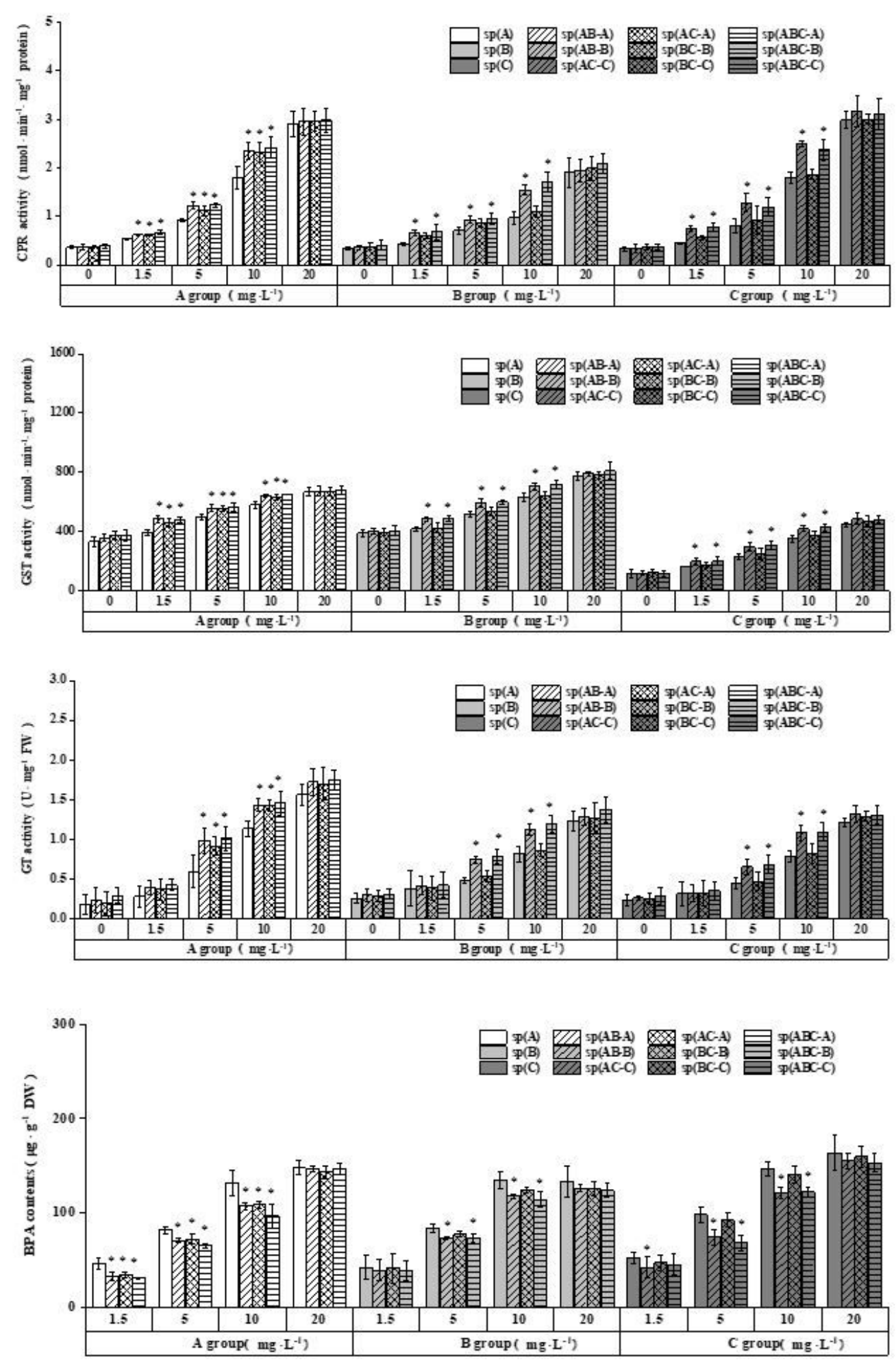

\section{Figure 6}

Effects of BPA on the CPR, GST, GT activities and BPA contents of leaves after ten days of exposure. The error bars indicate standard deviation $(n=3)$. The asterisk $\left(^{*}\right)$ indicates significant differences $(p<0.05)$ with compared to single species control $(\mathrm{sp}(\mathrm{A}), \mathrm{sp}(\mathrm{B}), \mathrm{sp}(\mathrm{C}))$, respectively. 


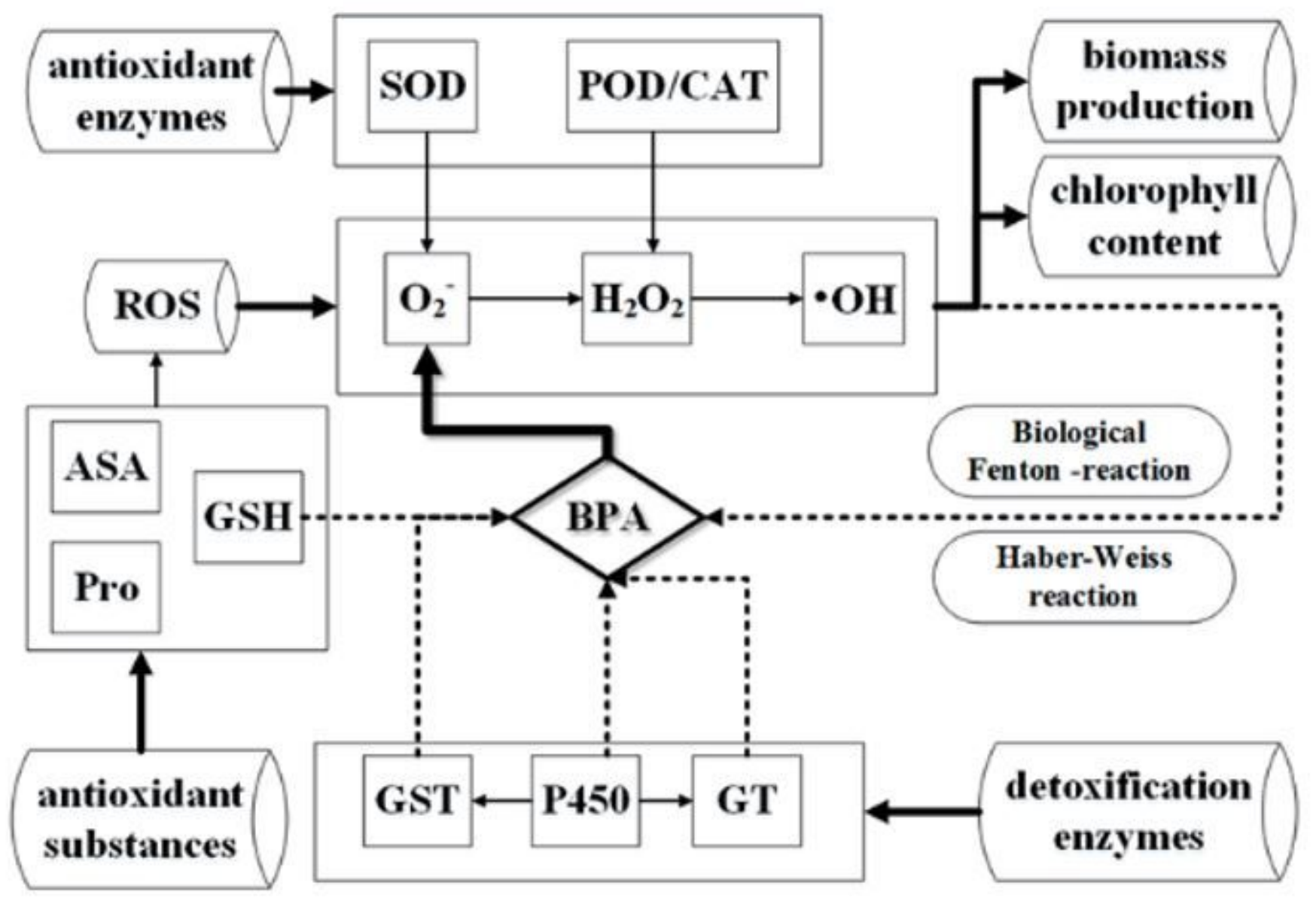

Figure 7

A proposed model depicting of the plant species compositions alleviate toxicological effects of BPA. 